\title{
ACTH-induced stress in weaned sows impairs LH receptor expression and steroidogenesis capacity in the ovary
}

\author{
H. S. Zhu' ${ }^{1}$, Z. Qian ${ }^{1}$, H. L. Liu ${ }^{2}$ and E. D. Bao ${ }^{1 *}$
}

\begin{abstract}
Background: Stress has been proved to impair the porcine reproduction soundly. Endocrine disruption, which is closely related to the persistent follicles, is possibly one of the results of stress, although the mechanism is unclear. Since the expression of luteinizing hormone receptor (LHR) in ovarian follicular wall and concentrations of steroid hormone in follicular fluid are related to the development of persistent follicles, this study is designed to evaluate the effect of administered adrenocorticotrophic hormone (ACTH) to weaned pigs on their ovarian steroidogenesis capacity and LHR expression.
\end{abstract}

Methods: Ten multiparous sows were weaned and randomly divided into two groups ( $n=5$ each). Sows received $1 \mathrm{IU} / \mathrm{kg}$ ACTH (ACTH group) or saline (control group) every $8 \mathrm{~h}$ from days 3-9 after jugular vein intubation. Blood samples were collected throughout the experiment, and ovaries were collected after slaughter on day 10. Follicular fluid (FF) was used to determine the steroid hormone concentrations. The ovarian follicle wall was obtained and stored in liquid nitrogen to detect mRNA levels.

Results: The plasma cortisol concentration was significantly $(P<0.01)$ elevated after ACTH injection. The estradiol $\left(E_{2}\right)$ and androstenedione (ASD) concentrations in FF were significantly lower $(P<0.05)$ in the ACTH group than in

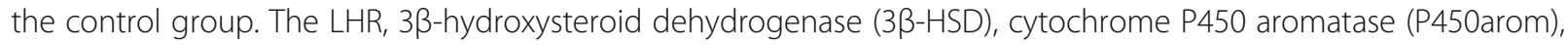
and cytochrome P450 17a-hydroxylase (P450c17) mRNA levels were significantly $(P<0.05)$ reduced in the ACTH group. The steroidogenic acute regulatory protein (StAR) level and cytochrome P450 side-chain cleavage (P450scc) was lower in the ACTH group than in the control group, but the difference was not statistically significant $(P>0.05)$. Immunostaining results revealed 3ß-HSD,P450c17, and LHR expression in theca cells, and P450arom expression in granulosa cells. Immunohistochemical staining showed significant differences in the distribution of 3ß-HSD, P450c17, LHR, and P450arom between the two groups.

Conclusions: These findings indicated that ACTH significantly diminished the LHR expression and steroidogenesis capacity of the ovaries of weaned sows.

Keywords: ACTH, Stress, Steroidogenesis, LH receptor, Weanling sows

\footnotetext{
*Correspondence: b_endong@njau.edu.cn

${ }^{1}$ College of Veterinary Medicine, Nanjing Agricultural University, Weigang 1,

Nanjing 210095, China

Full list of author information is available at the end of the article
} 


\section{Background}

Stress is a well-known factor influencing reproductive performance in animals [1] Stressors come in various forms, and events such as weaning, grouping, and transportation have all been shown to influence reproduction in pigs and the pigs' response to each of these stressors is different [2]. Responses to stress vary in response to factors such as type of stressor, duration, intensity, and individual variation between pigs [1-3]. It is difficult to compare and evaluate the different stressors that affect pig reproduction, particularly in long-term situations. A previous study found that ovarian cysts are an important disorder for sows, which accounted for $10 \%$ of reproductive problems in pigs [4]. However, little is known about ovarian cysts, because it may happen without the performance of reproduction confusion [4]. Although it is difficult to diagnose ovarian cysts, it is established that endocrine disruption is associated with ovarian cysts [5]. The confusion of endocrinological mechanisms plays a role in infertility by altering the physiology of gonadal tissues [5]. Stress results in alterations in hormonal events along with the immediate endocrine; some studies have reported that endocrine imbalance is the primary reason for the occurrence of ovarian cysts [6, 7]. Although stress-inducing practices such as sow crating and tethering have been gradually replaced by group penning to improve animal welfare, group penning can also give rise to stress among pigs due to animals pushing, riding, and biting one another [8]. Thus, stress is inevitable and difficult to evaluate. In pig production, many events can potentially cause stress and it is difficult to assess the precise relationship between stress and reproduction due to the varied number and type of stressors.

A series of studies have shown that reproduction in pigs is always impaired by stress through the neuroendocrine system [1,9-11]. Without exception, various types of stress can activate the hypothalamic-pituitary-adrenal (HPA) axis, affecting hormone release and ovarian function [12]. Activation of the HPA axis suppresses gonadotropin secretion and influences ovarian activity by increasing the production of glucocorticoids [12]. The HPA axis is activated in response to stress, triggering the release of corticotrophin-releasing hormone $(\mathrm{CRH})$ and vasopressin by the hypothalamus. Increased levels of $\mathrm{CRH}$ lead to increased $\mathrm{ACTH}$ release from the anterior lobe of the pituitary $[2,5]$. ACTH acts on the adrenal cortex, stimulating the release of glucocorticoid hormones (e.g., cortisol in pigs) and influencing the physiological state of the sexual organs and steroid hormone pathways [13]. Exogenous ACTH administration has been shown to affect not only the adrenal glands but also the reproductive organs and several hormonal pathways either directly or by alterations in the cortisol level [14]. At ovulation, increased estradiol-17 $\beta\left(\mathrm{E}_{2}\right)$ and decreased progesterone $\left(\mathrm{P}_{4}\right)$ concentrations in the plasma lead to increase in the frequency of $\mathrm{GnRH}$ secretion, contributing to the preovulatory LH surge [10]. Steroid hormones play a role in ovarian structures remote from the luteal or follicular cells where they are produced, and the process is realized by endocrine mechanisms $[5,15]$. Decrease in the levels of steroid hormone can influence follicular development and even ovulation [16-18]. In general, androgens are secreted in granulosa cells and converted to $E_{2}$ by P450arom; androgen levels are higher when the expression of the aromatase is suppressed, and this contributes to the formation of ovarian cysts [19]. Increased plasma cortisol levels lead to a decrease in the expression of steroidogenic enzymes and impair the synthesis capacity of $E_{2}$ [20]. When the plasma $E_{2}$ concentration is reduced, the positive feedback effect on $\mathrm{GnRH} / \mathrm{LH}$ secretion is weakened and the preovulatory LH surge is then suppressed, ultimately affecting the success of ovulation [21].

ACTH administration did not significantly alter the plasma $\mathrm{E}_{2}$ and $\mathrm{LH}$ concentrations compared to the control group [13]. A review reported that no significant differences were found in the $\mathrm{LH}$ levels between control animals and experimental animals injected with $\mathrm{ACTH}$, but the interval of the LH peak to ovulation showed a significant difference. The time from LH peak to ovulation was longer in the ACTH group than in the control group [12]. LH functions by binding to its receptors, and the LHR is the primary medium by which LH affects follicle development and maturation by stimulating the synthesis and secretion of steroid hormones [22].

Therefore, we aimed to study the effect of ACTH injection on the development and function of ovarian follicles; androstenedione levels; progesterone and $\mathrm{E}_{2}$ levels in follicular fluid (FF); LH receptor expression; and the expression of steroidogenic enzymes such as P450scc, P450c17, P450arom, StAR, and 3 $\beta$-hydroxysteroid dehydrogenase $(3 \beta-H S D)$ in granulosa and theca cells of the ovarian follicle. To this end, we induced long-term stress in weaned sows by ACTH administration for 7 days.

\section{Methods}

\section{Animals}

Ten multiparous Suhuai sows at parity 3-4 and weaning at $28 \mathrm{~d}$ were selected for the experiment. The average weight of the tested sows was $175 \pm 25 \mathrm{~kg}$. The animals were housed in individual pens, fed twice a day, and provided with water ad libitum.

\section{Experimental design}

\section{Grouping and jugular vein catheter}

The jugular vein was cannulated on the weaning day and defined as day 1 of the experiment. Sows were fixed to a test bench after they were sedated with thiopentone 
sodium. A cannula was passed into the exposed jugular vein, while the free end of the cannula was passed subcutaneously and fixed behind the ear with adhesive bandage. After the surgery, the sows were randomly divided into two groups: an ACTH group and a control group ( $n=5$ per group). From days $2-8$ after the surgery, animals in the ACTH group received $1 \mathrm{IU}$ ACTH $/ \mathrm{kg}$ body weight every $8 \mathrm{~h}$. The ACTH was obtained from porcine pituitary glands (A6303, Sigma, USA). Sows in the control group received the same dosage of saline $(0.09 \%)$ on the same schedule as the ACTH group. The cannula was filled with heparinized saline $(0.09 \%)$ to prevent coagulation.

\section{Blood sampling}

Blood samples were collected every $3 \mathrm{~h}$ starting from 9:00 am on day 2 until pro-estrus. After the start of estrus, blood samples were then collected every $1 \mathrm{~h}$. The blood samples $(10 \mathrm{~mL})$ were collected into a heparinized vacuum blood tubes, centrifuged for $10 \mathrm{~min}$ at $1000 \mathrm{~g}$, and stored at $-20{ }^{\circ} \mathrm{C}$ until analysis.

\section{Collections of FF and follicle tissues}

Porcine ovaries were collected within $10 \mathrm{~min}$ of slaughter of weaned sows. Follicles were then stripped from the ovary using sterile scissors and placed on ice. FF without blood was collected from each single follicle, and then stored at $-80{ }^{\circ} \mathrm{C}$ for $\mathrm{P}_{4}, \mathrm{E}_{2}$, and androstendione (ASD) assays. Meanwhile, follicular tissues were stripped from the follicles using sterile scissors, and the tissues were then stored at $-80{ }^{\circ} \mathrm{C}$ for extraction and analysis of mRNA.

\section{Detection of cortisol, $\mathrm{P}_{4}, \mathrm{E}_{2}$, and ASD levels in FF}

The P4, $E_{2}$, and ASD levels in follicular fluid were determined by ELISA assay kits (H089 and H102, Jiancheng, Nanjing, China; and 33-33720, TIANDZ, Beijing, China respectively) and the plasma cortisol level was evaluated by the same method (ANG-E31032P, Aoqing, Nanjing, China). All FF and plasma samples were centrifuged at $3000 \mathrm{rpm}$ for $20 \mathrm{~min}$ at $4{ }^{\circ} \mathrm{C}$. After centrifugation, all samples were diluted 1:5 in sample diluents and detected at $450 \mathrm{~nm}$ using a multimode reader (Infinite 200 PRO; Tecan, Geneva, Switzerland). The $\mathrm{E}_{2}: \mathrm{P}_{4}$ ratio was calculated after the $\mathrm{E}_{2}$ and $\mathrm{P}_{4}$ levels were detected in follicular fluid.

\section{Fluorescence quantitative real-time PCR}

Total RNA was isolated using TRIzol reagent (TrizolRNAiso Plus reagent, D9108A, Takara, China), and reverse transcription was carried out using Transcript Moloney murine leukemia virus kit (Invitrogen, Shanghai, China). For total RNA collection, $100 \mathrm{mg}$ of follicle tissue was homogenized with $1 \mathrm{~mL}$ RNA extraction buffer (TRIzol; Takara Biotechnology, co., Ltd.) in a Super Fine Homogenizer (623003, Fluko, Germany). Once the total RNA was extracted, its concentration was determined by measuring absorbance in a spectrophotometer (M200PRO; Tecan, Austria) at $260 \mathrm{~nm}$. The sequences of the lhr, star, p450scc, p450arom, p450c17, 33-hsd were obtained from the National Center for Biotechnology Information Genbank. Table 1 presents the sequences and sizes of the $l h r$, star, p450scc, p450arom, p450c17, and $3 \beta$-hsd genes.

\section{Immunohistochemical staining}

Ovaries of the tested sows were obtained within $10 \mathrm{~min}$ of slaughter. They were then fixed in $4 \%$ formalin solution buffer ( $\mathrm{pH}$ 7.4) for $24 \mathrm{~h}$, and embedded in paraffin. Serial 5 - $\mu \mathrm{m}$-thick sections of ovarian follicles were cut and the sections were mounted onto 3-aminopropyltriethoxysilane (APES)-coated slides.

Sections were deparaffinized in xylene and dehydrated in an ascending ethanol series, and washed three times in $\mathrm{PBS}$ for $3 \mathrm{~min}$ each time. Antigen retrieval was carried out in $0.01 \mathrm{M}$ sodium citrate buffer ( $\mathrm{pH}$ 6.0) in a microwave oven, and the sections were rinsed three times with PBS for 3 min each time. The sections were then immersed in 3\% hydrogen peroxide for $10 \mathrm{~min}$ to inactivate the endogenous peroxidase at room temperature. After inactivation, antigen retrieval was carried out in a microwave oven and nonspecific binding was blocked with 5\% BSA. The following primary antibodies were used: anti-CYP19A1 (1:100, A1336, ABclonal Technology, Wuhan, China), anti-CYP17A1 (1:100, A1373, ABclonal Technology, Wuhan, China), anti-33HSD (1:100, sc-30820, Santa Cruz Biotechnology, CA, USA), and anti-LHR (1:100, K-15, Santa Cruz Biotechnology, CA, USA). For the negative controls, 1\% bovine serum albumin was used instead of the primary antibody. Next, sections were incubated with horseradish peroxidase (HRP)-conjugated goat anti-rabbit $\lg G$ $(\mathrm{H}+\mathrm{L} ;$ 1:150 dilution, IH-0011; Dingguo, Beijing, China) for $1 \mathrm{~h}$ at $37^{\circ} \mathrm{C}$. The reactions were visualized by treatment with diaminobenzidine (DAB) (AR1022, Boster, Wuhan, China) for $15 \mathrm{~s}$.

Image-Pro Plus 6.0 software was used to evaluate the staining intensity by the average optical density (AOD). Ten typical fields were selected to estimate the percentage of immunopositive cells, and each field was examined twice by three authors.

\section{Statistical analysis}

Data of the ACTH and control groups were analyzed by independent sample $t$ test using Statistical Package for Social Science software (SPSS version 20.0 for Windows). All data are represented as the mean \pm standard deviation (SD) and a $\mathrm{P}$ value of $<0.05$ was considered statistically significant. 
Table 1 Sequences and sizes of all tested genes

\begin{tabular}{|c|c|c|c|}
\hline Gene & $\begin{array}{l}\text { Reference } \\
\text { sequence }\end{array}$ & Primer sequence $\left(5^{\prime}-3^{\prime}\right)$ & Size \\
\hline \multirow[t]{2}{*}{ LHR } & \multirow[t]{2}{*}{ NM-214449.1 } & sense GCTCACCCAAGACACTCC & \multirow[t]{2}{*}{190} \\
\hline & & antisense CACATGAGGAAACGAGGC & \\
\hline \multirow[t]{2}{*}{ StAR } & \multirow[t]{2}{*}{ NM-213755.2 } & sense GGCAAGGCTCTTCTAACT & \multirow[t]{2}{*}{99} \\
\hline & & antisense TAGACACGAAAGGGCTCA & \\
\hline \multirow[t]{2}{*}{ P450sce } & \multirow[t]{2}{*}{ NM-214427.11 } & sense CCAGCATTACCAGAAGCC & \multirow[t]{2}{*}{92} \\
\hline & & antisense GAGCCATTACCTCCGTGT & \\
\hline \multirow[t]{2}{*}{ P450arom } & \multirow[t]{2}{*}{ NM-214429.1 } & sense AAGAAGGGTCACAACAAG & \multirow[t]{2}{*}{165} \\
\hline & & antisense AAGAAAGCCAGTGAGCAG & \\
\hline \multirow[t]{2}{*}{ P450c17 } & \multirow[t]{2}{*}{ NM-214428.1 } & sense ATGATCCAAGCCAAGACG & \multirow[t]{2}{*}{140} \\
\hline & & antisense TTACCACAGAGGCAGAAG & \\
\hline \multirow[t]{2}{*}{$3 \beta-H S D$} & \multirow[t]{2}{*}{ NM-001004049.1 } & sense CCTGGCAAGTATTTCTCGG & \multirow[t]{2}{*}{107} \\
\hline & & antisense CCAGCAACAAGTGGACGAT & \\
\hline \multirow[t]{2}{*}{$\beta$-actin } & \multirow[t]{2}{*}{ NM-001167795.1 } & sense CTCCATCATGAAGTGCGACGT & \multirow[t]{2}{*}{114} \\
\hline & & $\begin{array}{l}\text { antisense GTGATCTCCTTCTGCATCCT } \\
\text { GTC }\end{array}$ & \\
\hline
\end{tabular}

\section{Results}

\section{Plasma cortisol concentrations in the ACTH and control} groups

We evaluated the plasma cortisol levels in sows in the $\mathrm{ACTH}$ and control groups at four different time points in order to evaluate their stress levels (Fig. 1). The plasma cortisol levels were significantly elevated $(P<0.01)$ in the ACTH group than in the control group at 16,88 , and $160 \mathrm{~h}$ after $\mathrm{ACTH}$ injection. The cortisol level in the ACTH group was the highest at the second tested time point $(16 \mathrm{~h})$ compared to the other

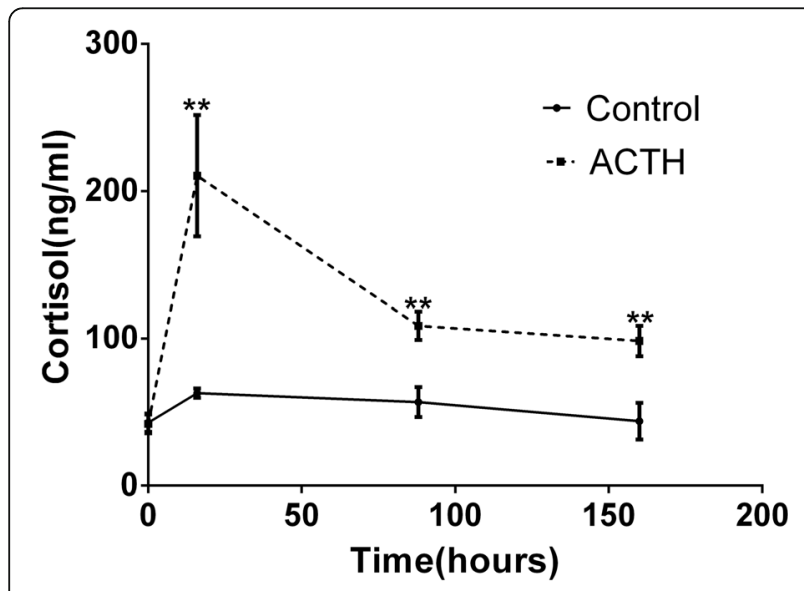

Fig. 1 Plasma cortisol concentrations at four time points in sows of the control and $\mathrm{ACTH}$ groups. Plasma cortisol concentrations at four different time point $(0,16,88$, and $160 \mathrm{~h})$ in the ACTH and control groups. After ACTH injection, the cortisol concentrations showed a significant increase $(P<0.01)$. ${ }^{*}$ Values were statistically different at $p$ $<0.01$ compared to the control group time points in the ACTH group $(0,88$, and $160 \mathrm{~h})$, and this difference was significant $(P<0.01)$. The cortisol concentration in the ACTH group declined sharply at 88 h. Thereafter, the cortisol concentration remained stable (from 88-160 h) and remained higher than the corresponding levels in the control group. The results revealed that plasma cortisol levels were maintained at a high level in the ACTH group, indicating successful stress induction in the ACTH model group.

\section{Steroid hormone levels in follicular fluid}

Figure 2 shows the concentrations of steroid hormones such as $\mathrm{E}_{2}, \mathrm{ASD}$, and $\mathrm{P}_{4}$ in the ovarian follicular fluid of sows treated with $\mathrm{ACTH}$ for 7 days and control sows. The results revealed that the $\mathrm{E}_{2}$ and ASD levels had significantly decreased in the ovarian follicular fluid of the ACTH group (90.6 ng/L and $14.8 \mathrm{nmol} / \mathrm{L}$, respectively; $P<0.05)$ compared to the corresponding levels in the control group $(177.8 \mathrm{ng} / \mathrm{L}$ and $17.9 \mathrm{nmol} / \mathrm{L}$, respectively). The $\mathrm{P}_{4}$ concentration of the ACTH group did not significantly decrease from that of the control group (71.5 vs. $80.2 \mathrm{ng} / \mathrm{mL}$, respectively; $P>0.05$ ). Although the $E_{2} / P_{4}$ ratios in both groups were $>1$, it was lower in the ACTH group than in the control group (Fig. 2d).

\section{Relative mRNA transcription levels of steroidogenic enzymes and LHR}

We then analyzed the corresponding mRNA transcription levels such as cyp11a1, cyp17a1, cyp19a1, $3 \beta$-hsd, star, and $l h r$ by real-time quantitative polymerase chain reaction (RT-PCR). The transcription levels were normalized to the corresponding $\beta$-actin levels (Fig. 3). All the tested genes were associated with steroidogenic enzymes showed a lower transcription levels. The results revealed that the transcription levels of $l h r, 3 \beta$-hsd, cyp17a1, and cyp19a1 were significantly decreased $(P<0.05)$ in the ACTH group. The cyp11a1 and star mRNA levels showed a similar trend; however, there was no significant reduction in their levels between the two groups $(P>0.05)$.

\section{Immunohistochemical staining}

Figure 4 shows the distributions of CYP17A1, CYP19A1, and $3 \beta-$ HSD in the follicular wall of sow ovaries in both the groups. Immunohistochemical staining revealed that $3 \beta-$ HSD and CYP17A1 are primarily localized in the theca cells. Meanwhile, positive staining of CYP19A1 is detected in granulosa cells, while some weak signals are observed in theca cells. Positive staining for LHR is observed in the ovarian theca cells in both the groups.

Immuno-expression level

Based on the AOD, the immunoreactivities of 3 3 -HSD, CYP19A1, CYP17A1, and LHR are significantly reduced 

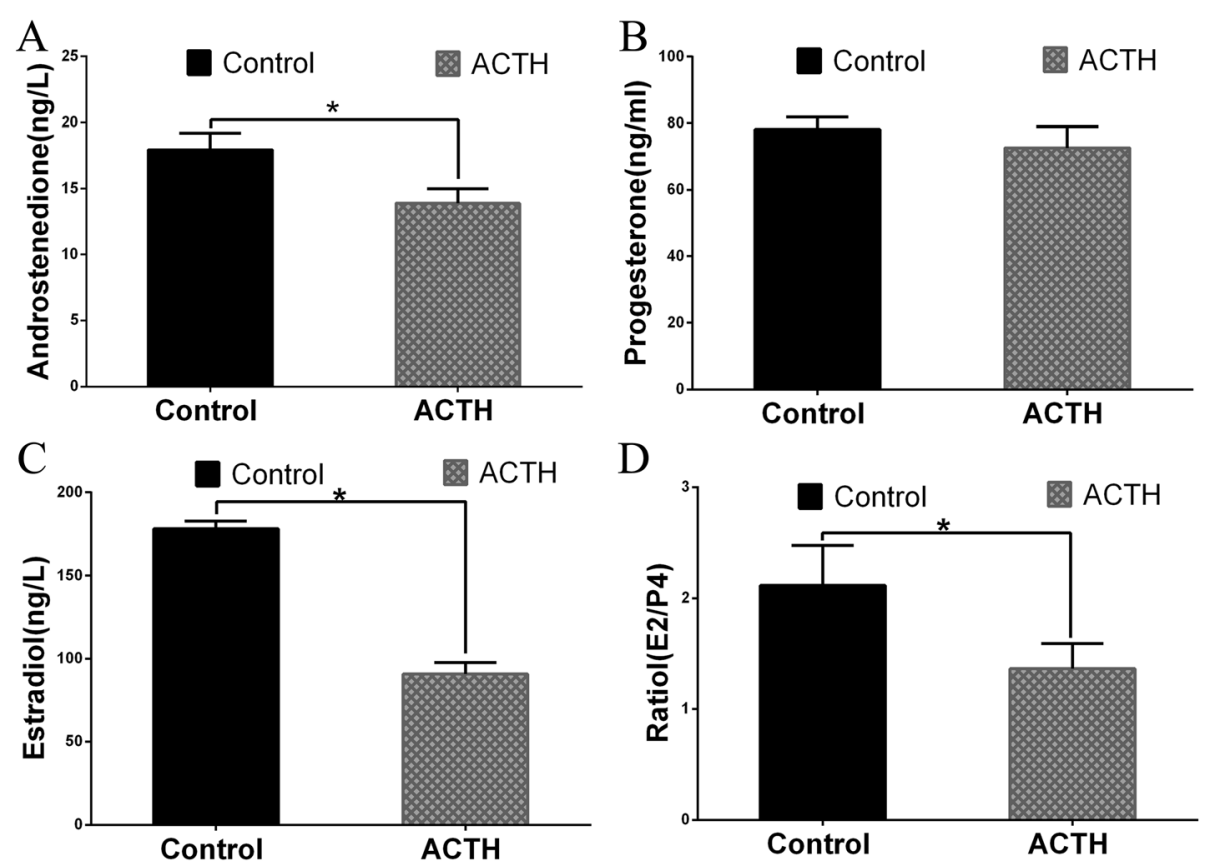

Fig. 2 Changes in steroid hormone concentrations in ovarian follicular fluid Changes in the concentrations of (a) androstenedione (SD), (b) progesterone $\left(\mathrm{P}_{4}\right),(\mathbf{c})$ estradiol $\left(\mathrm{E}_{2}\right)$, and $(\mathbf{d})$ the $\mathrm{E}_{2} / \mathrm{P}_{4}$ ratio in the follicular fluid of weaned sows with and without $A C T H$. After ACTH injection, the ASD, $E_{2}$, and $E_{2} / P_{4}$ ratio were all significantly decreased $(P<0.05)$ compared to the corresponding values in the control group. ${ }^{*}$ Values were statistically significant at $p<0.05$ compared to the control group

in the theca cells of the ACTH group compared to those of the control group ( $\mathrm{P}<0.05$; Fig. 5). The AODs of 33-HSD and CYP19A1 are higher than those of CYP17A1 and LHR.

\section{Discussion}

Although it is commonly known that stress induces disorders in follicular development and ovulation, the underlying

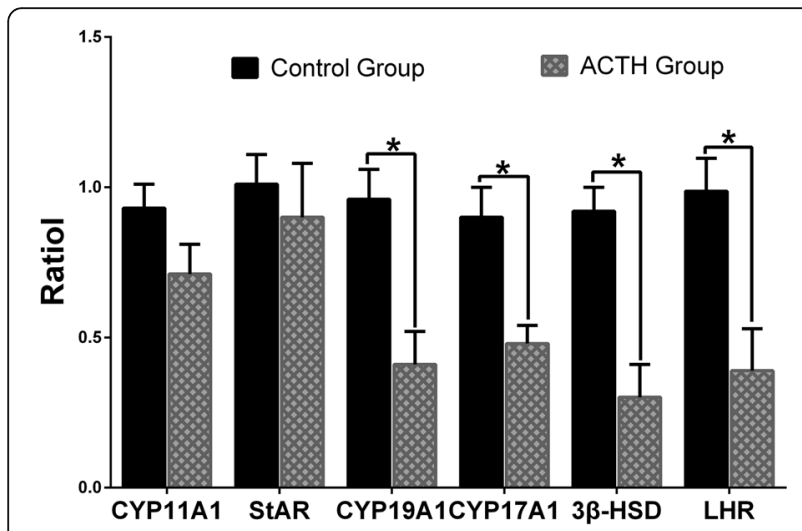

Fig. 3 mRNA levels of steroidogenic enzymes and LHR Effect of ACTH treatment on the transcription levels of star, p450scc, p450arom, p450c17, 3 $\beta$-hsd, and Ihr relative to the $\beta$-actin transcription level in the follicular wall of the control and ACTH groups. *Differences in values were statistically significant at $p<0.05$ compared to the control group mechanism remains unclear. ACTH administration has been reported to simulate the stress response, which is reflected by the plasma cortisol response, and influenced reproduction in pigs $[8,9,11,13,23,24]$. In the present study, we administered sows with repeated ACTH injections to mimic stress; this resulted in an increase in the plasma cortisol concentration in the sows that were treated with ACTH but not in the untreated control sows, indicating successful establishment of a stress model. Previous studies mainly focus on the changes in the hormone levels in plasma, but hormone levels were not obviously affected by ACTH administration [8, 13]. Therefore, in our study we investigated changes in the steroid hormone levels in follicular fluid and LHR expression in the ovarian follicular wall in the stress model.

Cortisol is a sensitive indicator of stress, and our study found that sows with ACTH-induced stress had much higher plasma cortisol concentrations than control sows; our findings are in agreement with those reported previously $[2,25]$. In addition to the higher plasma cortisol concentration, sows in the ACTH group also showed reduced $E_{2}$ and ASD levels in $F F$ and lower $E_{2} / P_{4}$ ratio compared to the corresponding values in the control group. Interestingly, the $\mathrm{P}_{4}$ concentration in FF did not significantly differ between the two groups. Ovarian steroidogenesis is known to be a multistep process involving many key enzymes [26]. The above results indicate that ACTH may not significantly affect the transcription 


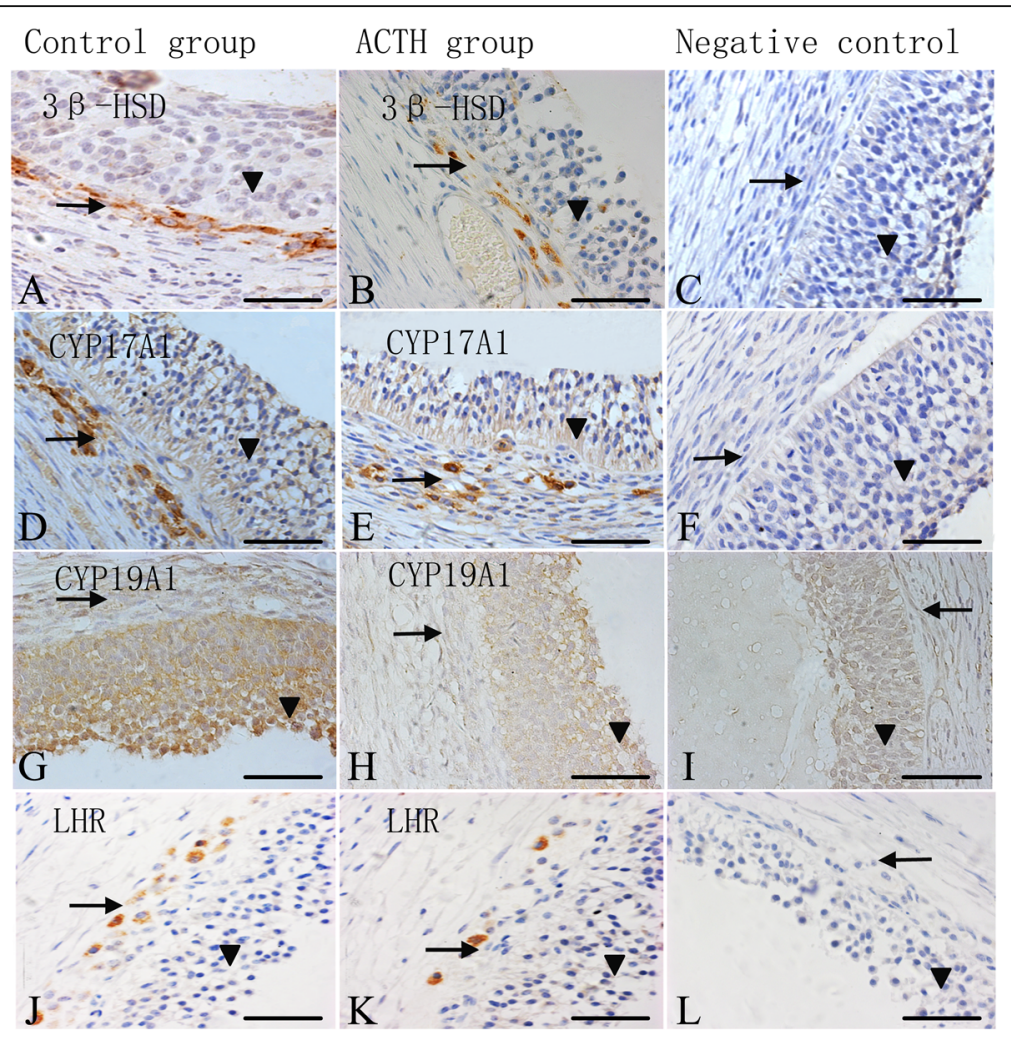

Fig. 4 Localization of 3ß-HSD, CYP17A1, CYP19A1, and LHR in sow ovaries Immunohistochemical staining of sow ovaries. Samples are counterstained with Mayer's hematoxylin. Bars $=50 \mu \mathrm{m}$. The immunolocalization of 3ß-HSD $(\mathbf{a}, \mathbf{b})$, CYP17A1 $(\mathbf{d}, \mathbf{e})$, CYP19A1 $(\mathrm{G}, \mathrm{H})$, and LHR (j, k) in the follicular walls of sows during the control and ACTH groups. The column on the right illustrates the immunohistochemical staining of the respective negative controls: (c) $3 \beta-$

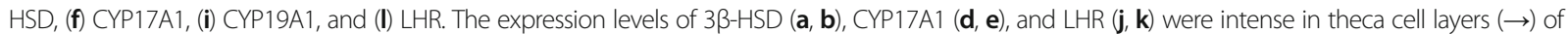
both the control and ACTH-treated sows. Note the intense reactivity for CYP19A1 $(\mathbf{g}, \mathbf{h})$ in the granular cell layers $(\mathbf{\nabla})$ of both the groups. ACTH group: After 7 days of ACTH treatment, the expression level of 3ß-HSD (B), CYP17A1 (e), LHR (k), and CYP19A1 (h) were significantly reduced compared to the control group

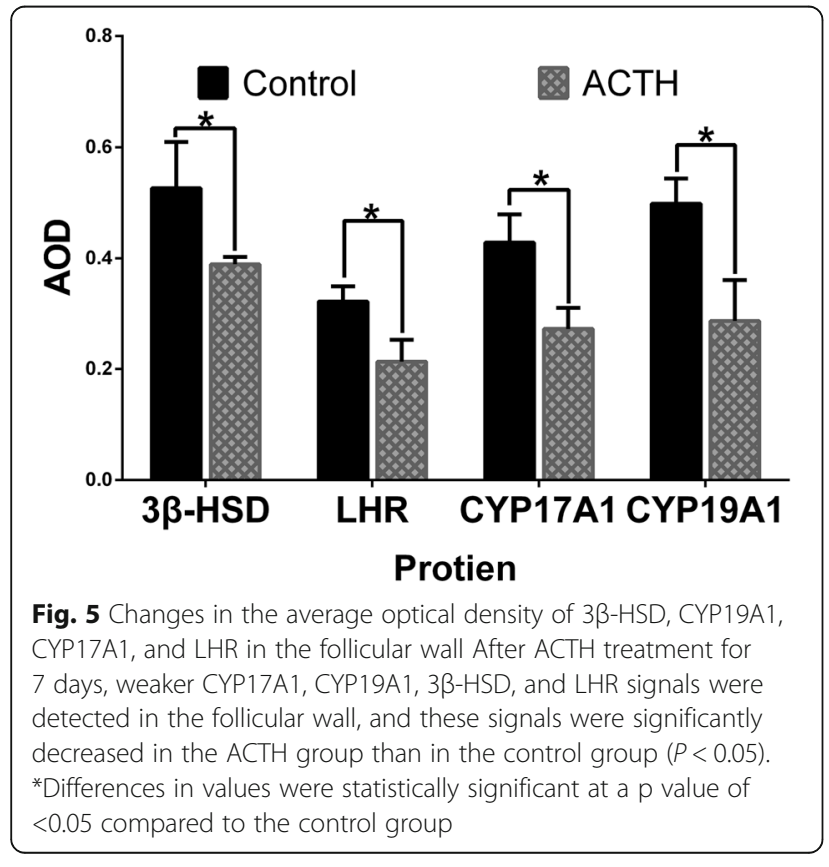

of certain key enzymes. Cortisol, which is released by adrenal glands due to exogenous $\mathrm{ACTH}$, is capable of damaging ovarian function $[2,27,28]$. ACTH, which is secreted from the pituitary gland, can induce cortisol secretion by acting on the adrenal gland [10, 25]. Increase in the plasma cortisol concentration would initiate the negative feedback of $E_{2}$, which would then suppress the frequency or amplitude of $\mathrm{GnRH}$, reducing the secretion of gonadotrophin [28]. At the hypothalamo-pituitary level, gonadotrophin inhibition influences ovulation and triggers the formation of small ovarian cysts [24, 29]. Hormonal interaction of the HPA and hypothalamic-pituitarygonadal (HPG) axes contributes to reproductive problems in female pigs [5]. Increased cortisol concentrations can suppress the synthesis of steroid hormones and can even impair the preovulatory LH surge, resulting in ovulation failure $[27,28]$. Suppression of the LH surge can impair follicle development and estrogen synthesis as well as increase the formation of follicular atresia [17]. Steroid hormone release is controlled by endocrine mechanisms, and changes in the concentrations of steroid hormones 
will influence reproductive function [5]. Steroid hormones are important factors affecting ovarian follicle growth and ovulation in weaning sows. As paracrine/autocrine agents, these hormones can play roles on or within the cells where they were produced [15].

Ovarian steroidogenesis is a multistep process involving several key enzymes [26]. Enhanced $E_{2}$ biosynthesis ability is always accompanied by upregulation of LHR and some steroidogenic genes [30]. In the present study, the follicular fluid of the ACTH group had reduced $E_{2}$ and ASD concentrations. Accordingly, the $l h r, 3 \beta$ - $h s d$, cyp19a1, and cyp17a1 mRNA levels were also reduced in the ACTH group compared to the control group; this reduction may be associated with the high plasma cortisol levels induced by ACTH. The frequency or amplitude of GnRH could be suppressed with the increased in the plasma cortisol level [28]. In addition, treatment with a GnRH receptor antagonist has been shown to decrease $\mathrm{LH}$ secretion and reduce the lhr, cyp19a1, and cyp17a1 mRNA levels [31]. Compared to the control group, the ACTH group had a lower $\mathrm{E}_{2} / \mathrm{P}_{4}$ ratio, and the $l h r, c y p 19 a 1$, and cyp17a1 levels were lower in estrogen-inactive follicles than in estrogen-active follicles [32]. The mRNA and protein levels of these enzymes were related to the biosynthesis and transfer of androgens. In previous literature, $3 \beta-H S D$ was shown to convert pregnenolone into $\mathrm{P}_{4}$ and transfer this hormone outside the mitochondria, while P450c17 was shown to produce ASD via 17-hydroxylation of $\mathrm{P}_{4}$ [33]. The results of the immunohistochemical staining in our study revealed positive signals of P450c17 and 3 3 -HSD distributed in theca cells, and these positive signals were reduced in the ACTH group compared to the control group. When the $3 \beta$-HSD expression level is reduced, it interferes with the ability of $\mathrm{P}_{4}$ transfer, resulting in ASD biosynthesis and reduced $\mathrm{P}_{4}$ concentration. Similarly, the suppression of $\mathrm{P} 450 \mathrm{c} 17$ reduces the 17-hydroxylation activity of this enzyme, consequently affecting ASD biosynthesis [18]. Except for aromatization, which occurs in granulosa cells, all other processes of steroidogenesis occur in theca cells. P450arom is expressed in granulosa cells and is the last key enzyme that plays a role in the formation of estrogens from androgens [34]. Disruption of ovarian steroid synthesis in sows may be associated with defects in the aromatase complex, which influences hormone conversion in peripheral fat tissue [10]. Suppression of P450arom activity can reduce the $E_{2}$ concentration in $\operatorname{FF}[35,36]$. In a study on women with polycystic ovary syndrome (PCOS), the P450arom expression levels in granulosa cells were very low and undetectable, indicating that the process of conversion of androgens into estrogens was disturbed, affecting the development of the ovarian follicle [37].

Estrogens can regulate the development of ovarian follicles by stimulating the proliferation of granulosa cells [38]. Decrease in the estrogen levels could influence the
LH surge [39] and the LHR expression in the ovary [22]. LHR expression is a vital mediator for the various functions of LH in sows, in including ovulation. $\mathrm{LH}$ can influence the $\mathrm{P}_{4}$ and ASD production and induce ovulation by binding to the $\mathrm{LH}$ receptor [40]. A previous study reported that inactivation of LHR by gene mutation affected follicular development at all stages [41]. Glucocorticoids have been shown to influence the responsiveness of gonadal to $\mathrm{LH}$ and the expressions of LHR [42]. LHR production increases with follicle development and matures before ovulation [43] while the expression would be influenced by many elements such as the circulating LH levels [31]. The cortisol that is produced in response to stress suppresses GnRH secretion and decreases the LH level [28]. The ACTH-induced increase in the plasma cortisol level affects the LHR expression in ovarian follicular walls. In addition, LHR expression is related to estrogen activity, and LHR expression has been found to be lower in estrogeninactive follicles than in estrogen-active follicles [32].

\section{Conclusions}

The present study demonstrated that higher cortisol levels, induced in response to stress, affected the growth and ovulation of follicles. ACTH injection over longterm increased the plasma cortisol concentration, which reduced the steroidogenic hormone levels and LHR expression in the ovaries of weaned sows.

\section{Abbreviations}

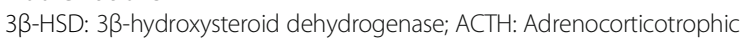
hormone; AOD: Average optical density; ASD: Androstenedione; BSA: Bovine serum albumin; $\mathrm{CRH}$ : Corticotropin releasing hormone; CYP11A1: Cytochrome P450 family 11 subfamily A member 1; CYP17A1: Cytochrome P450 family 17 subfamily A member 1; CYP19A1: Cytochrome P450 family 19 subfamily A member 1; E2: Estradiol; FF: Follicular fluid; GnRH: Gonadotropinreleasing hormone; HPA: Hypothalamic-pituitary-adrenal; HPG: Hypothalamic-pituitarygonadal; LH: Luteinizing hormone; LHR: Luteinizing hormone receptor; mRNA: Messenger ribose nucleic acid; P4: Progesterone; P450arom: Cytochrome P450 aromatase; P450c17: Cytochrome P450 17a-hydroxylase;

P450scc: Cytochrome P450 side-chain cleavage; PBS: Phosphate buffer saline; StAR: Steroidogenic acute regulatory protein.

\section{Acknowledgments \\ None}

\section{Funding}

The current study was supported by grants from the National Key Basic Research Program of China (973 Program; grant no. 2014CB138502), the National Natural Science Foundation of China (grant no.31602027), the National Natural Science Foundation of China (grant no.31672520), the National Natural Science Foundation Of China (grant no. 31372403), Jiangsu Natural Science Foundation of China (grant no. BK20160732), China Postdoctoral Science Foundation(2016 M591860), the Priority Academic Program Development of Jiangsu Higher Education Institutions, Graduate Research and Innovation Projects in Jiangsu Province and the Sino-German Agricultural Cooperation

Project of the Federal Ministry of Food, Agriculture and Consumer Production, Berlin, Germany.

Availability of data and materials Not applicable. 


\section{Authors' contributions}

EDB and HSZ designed this study. HSZ contributed to data analysis and wrote the manuscript. HSZ and ZQ performed most of the experiment. HLL helped with revision of the manuscript. All authors read and approved the final manuscript.

\section{Competing interests}

The authors declare that they have no competing interests.

\section{Consent for publication}

Not applicable.

\section{Ethics approval and consent to participate}

All the experiments were performed in accordance with the guidelines of the Animal Ethics Committee of Jiangsu Province (China). The study protocol was approved by the Animal Care and Use Committee of Nanjing Agricultural University (Nanjing, China).

\section{Author details}

'College of Veterinary Medicine, Nanjing Agricultural University, Weigang 1 , Nanjing 210095, China. ${ }^{2}$ College of Animal Science and Technology, Nanjing Agricultural University, Nanjing 210095, China.

\section{Received: 19 October 2016 Accepted: 4 November 2016}

\section{Published online: 14 November 2016}

\section{References}

1. Dobson $\mathrm{H}$, Smith RF. What is stress, and how does it affect reproduction? Anim Reprod Sci. 2000;60-61:743-52.

2. Einarsson S, Brandt Y, Lundeheim N, Madej A. Stress and its influence on reproduction in pigs: a review. Acta Vet Scand. 2008;50:48.

3. Wingfield JC, Sapolsky RM. Reproduction and resistance to stress: When and how. J Neuroendocrinol. 2003;15:711-24.

4. Castagna CD, Peixoto CH, Bortolozzo FP, Wentz I, Neto GB, Ruschel FC. Ovarian cysts and their consequences on the reproductive performance of swine herds. Anim Reprod Sci. 2004;81:115-23.

5. Szulanczyk-Mencel K, Rzasa A, Bielas W. Relationships between ovarian cysts and morphological and hormonal state of ovarian cortex in sows. Anim Reprod Sci. 2010;121:273-8.

6. Hamilton SA, Garverick HA, Keisler DH, Xu ZZ, Loos K, Youngquist RS, Salfen BE. Characterization of ovarian follicular cysts and associated endocrine profiles in dairy cows. Biol Reprod. 1995;53:890-8.

7. Prunier A, Quesnel H. Nutritional influences on the hormonal control of reproduction in female pigs. Livest Prod Sci. 2000;63:1-16.

8. Brandt Y, Lang A, Madej A, Rodriguez-Martinez H, Einarsson S. Impact of ACTH administration on the oviductal sperm reservoir in sows: the local endocrine environment and distribution of spermatozoa. Anim Reprod Sci. 2006;92:107-22.

9. Hennessy DP, Williamson P. The effects of stress and of ACTH administration in hormone profiles, oestrus and ovulation in pigs. Theriogenology. 1983;20:13-26.

10. Ribadu AY, Nakada K, Moriyoshi M, Zhang WC, Tanaka Y, Nakao T. The role of LH pulse frequency in ACTH-induced ovarian follicular cysts in heifers. Anim Reprod Sci. 2000;64:21-31.

11. Razdan P, Mwanza AM, Kindahl H, Rodriguez-Martinez H, Hulten F, Einarsson S. Effect of repeated ACTH-stimulation on early embryonic development and hormonal profiles in sows. Anim Reprod Sci. 2002;70:127-37.

12. Madej A, Lang A, Brandt $Y$, Kindahl H, Madsen MT, Einarsson S. Factors regulating ovarian function in pigs. Domest Anim Endocr. 2005;29:347-61.

13. Brandt $Y$, Lundeheim N, Madej A, Rodriguez-Martinez $H$, Einarsson S. Effects of ACTH injections during estrus on concentrations and patterns of progesterone, estradiol, LH, and inhibin alpha and time of ovulation in the sow. Domest Anim Endocr. 2007;32:122-37.

14. Vänttinen T, Kuulasmaa T, Liu J, Voutilainen R. Expression of Activin/Inhibin Receptor and Binding Protein Genes and Regulation of Activin/Inhibin Peptide Secretion in Human Adrenocortical Cells. J Clin Endocr Metab. 2002; 87:4257-63

15. Schams D, Berisha B. Steroids as local regulators of ovarian activity in domestic animals. Domest Anim Endocr. 2002;23:53-65.

16. Guthrie HD, Cooper BS, Welch GR, Zakaria AD, Johnson LA. Atresia in Follicles Grown after Ovulation in the Pig: Measurement of Increased
Apoptosis in Granulosa Cells and Reduced Follicular- Fluid Estradiol-17-Beta. Biol Reprod. 1995:52:920-7.

17. Barb CR, Kraeling RR, Rampacek GB, Fonda ES, Kiser TE. Inhibition of ovulation and $\mathrm{LH}$ secretion in the gilt after treatment with $\mathrm{ACTH}$ or hydrocortisone. J Reprod Fertil. 1982;64:85-92.

18. Ortega I, Villanueva JA, Wong DH, Cress AB, Sokalska A, Stanley SD, Duleba AJ. Resveratrol potentiates effects of simvastatin on inhibition of rat ovarian theca-interstitial cells steroidogenesis. J Ovarian Res. 2014;7:21.

19. Gregoraszczuk EL, Rak-Mardyla A. Supraphysiological leptin levels shift the profile of steroidogenesis in porcine ovarian follicles toward progesterone and testosterone secretion through increased expressions of CYP11A1 and 17 -HSD: a tissue culture approach. Reproduction. 2013;145:311-7.

20. Mankiewicz JL, Godwin J, Holler BL, Turner PM, Murashige R, Shamey R, Daniels HV, Borski RJ. Masculinizing effect of background color and cortisol in a flatfish with environmental sex-determination. Integr Comp Biol. 2013; 53:755-65.

21. Evans NP, Dahl GE, Mauger D, Karsch FJ. Estradiol Induces Both Qualitative and Quantitative Changes in the Pattern of Gonadotropin-ReleasingHormone Secretion during the Presurge Period in the Ewe. Endocrinology. 1995;136:1603-9.

22. Lei ZM, Rao CV. Neural actions of luteinizing hormone and human chorionic gonadotropin. Semin Reprod Med. 2001;19:103-9.

23. Larzul C, Terenina E, Foury A, Billon Y, Louveau I, Merlot E, Mormede P. The cortisol response to ACTH in pigs, heritability and influence of corticosteroid-binding globulin. Animal. 2015;9:1929-34.

24. Scholten JA, Liptrap RM. A role for the adrenal cortex in the onset of cystic ovarian follicles in the sow. Can J Comp Med. 1978;42:525-33.

25. Lang A, Kaeoket K, Kindahl H, Madej A, Einarsson S. Influence of CRH and ACTH administration on endocrine profile and ovulation in sows. Reprod Domest Anim. 2004;39:181-9.

26. Aluru N, Vijayan MM. Aryl hydrocarbon receptor activation impairs cortisol response to stress in rainbow trout by disrupting the rate-limiting steps in steroidogenesis. Endocrinology. 2006;147:1895-903.

27 Einarsson S, Ljung A, Brandt $Y$, Hager M, Madej A. Impact of exogenous ACTH during pro-oestrus on endocrine profile and oestrous cycle characteristics in sows. Reprod Domest Anim. 2007:42:100-4.

28 Macfarlane MS, Breen KM, Sakurai H, Adams BM, Adams TE. Effect of duration of infusion of stress-like concentrations of cortisol on follicular development and the preovulatory surge of LH in sheep. Anim Reprod Sci. 2000:63:167-75.

29 Smith ER, Johnson J, Weick RF, Levine S, Davidson JM. Inhibition of the reproductive system in immature rats by intracerebral implantation of cortisol. Neuroendocrinology. 1971;8:94-106

30 Cai L, Sun A, Li H, Tsinkgou A, Yu J, Ying S, Chen Z, Shi Z. Molecular mechanisms of enhancing porcine granulosa cell proliferation and function by treatment in vitro with anti-inhibin alpha subunit antibody. Reprod Biol Endocrinol. 2015:13:26.

31 Luo WX, Gumen A, Haughian JM, Wiltbank MC. The Role of Luteinizing Hormone in Regulating Gene Expression During Selection of a Dominant Follicle in Cattle. Biol Reprod. 2011;84:369-78.

32 Nimz M, Spitschak M, Schneider F, Furbass R, Vanselow J. Down-regulation of genes encoding steroidogenic enzymes and hormone receptors in late preovulatory follicles of the cow coincides with an accumulation of intrafollicular steroids. Domest Anim Endocr. 2009;37:45-54.

33 Biran D, Braw-Tal R, Gendelman M, Lavon Y, Roth Z. ACTH administration during formation of preovulatory follicles impairs steroidogenesis and angiogenesis in association with ovulation failure in lactating cows. Domest Anim Endocr. 2015;53:52-9.

34 Carreau S, Bourguiba DS, Lambard S, Galeraud-Denis I, Genissel C, Levallet J. Reproductive system: aromatase and estrogens. Mol Cell Endocrino. 2002; 193:137-43.

35 Guthrie HD, Bolt DJ, Cooper BS. Changes in Follicular Estradiol-17-Beta, Progesterone and Inhibin Immunoactivity in Healthy and Atretic Follicles during Preovulatory Maturation in the Pig. Domest Anim Endocr. 1993; 10:127-40.

36 Guthrie HD, Cooper BS, Welch GR, Zakaria AD, Johnson LA. Atresia in Follicles Grown after Ovulation in the Pig - Measurement of Increased Apoptosis in Granulosa-Cells and Reduced Follicular-Fluid Estradiol-17-Beta. Biol Reprod. 1995;52:920-7.

37 Li X, Zhang H, Sheng X, Li B, Zhou J, Xu M, Weng Q, Watanabe G, Taya K. Immunoreactivities of androgen receptor, estrogen receptors, p450arom, 
p450c17 proteins in wild ground squirrels ovaries during the nonbreeding and breeding seasons. J Ovarian Res. 2012;5:26.

38 Hsueh AJ, Adashi EY, Jones PB, Welsh Jr TH. Hormonal regulation of the differentiation of cultured ovarian granulosa cells. Endocr Rev. 1984;5:76-127.

39 Garverick HA, Polge C, Flint AP. Oestradiol administration raises luteal LH receptor levels in intact and hysterectomized pigs. J Reprod Fertil. 1982;66: $371-7$.

40 Edson MA, Nagaraja AK, Matzuk MM. The mammalian ovary from genesis to revelation. Endocr Rev. 2009;30:624-712.

41 Themmen APN, Huhtaniemi IT. Mutations of gonadotropins and gonadotropin receptors: elucidating the physiology and pathophysiology of pituitary-gonadal function. Endocr Rev. 2000;21:551-83.

42 Sapolsky RM. How Do Glucocorticoids Influence Stress Responses? Integrating Permissive, Suppressive, Stimulatory, and Preparative Actions. Endocr Rev. 2000;21:55-89.

43 Yung Y, Aviel-Ronen S, Maman E, Rubinstein N, Avivi C, Orvieto R, Hourvitz A. Localization of luteinizing hormone receptor protein in the human ovary. Mol Hum Reprod. 2014;20:844-9.

Submit your next manuscript to BioMed Central and we will help you at every step:

- We accept pre-submission inquiries

- Our selector tool helps you to find the most relevant journal

- We provide round the clock customer support

- Convenient online submission

- Thorough peer review

- Inclusion in PubMed and all major indexing services

- Maximum visibility for your research

Submit your manuscript at www.biomedcentral.com/submit
C) Biomed Central 